\title{
HAK ASASI MANUSIA DALAM ISLAM
}

\section{Laila Rahmawati}

\begin{abstract}
This article tries to describe the concept of Human Rights in the West and the response of Islam to them. In its history, it was Magna Charta in England that initiated the formulation of Human Rights in the West in 1512. Then It was followed by The Bill of right in 1689; The American Declaration of Independence in 1776; and The French Declaration in 1789 that resulted in The rule of law. Human Rights entered a new phase after The United Nations had declared the International Human Rights in

1984, that is The Universal Declaration of Human Rights. From that time on, Human Rights has become a global issue, continually discussed and responded to by many including Muslim scholars. In the West, the concept of Human Right is based merely on human values (anthropocentric) so that the responsibility is restricted to human beings. Based on this, this concept is different from Islamic concept on Human Rights because the former is based on secular values while the later is based on human values and divine values. Normatively, the idea of Human Rights is relevant to Islamic idea. The reason is that, based on their fitrah as creatures, human beings extremely expect the maintenance of their main needs (Al- umur al-Daruriyyah). Therefore, Human Rights are suitable with the purpose of syari'ah (maqasid al-Syari), that is to maintain religion, reason, heredity dan property.
\end{abstract}

\section{Keyword : Islam, Human Rights}

\section{Pendahuluan}

Secara umum term hak-hak asasi manusia dinamai dengan hak-

hak yang melekat pada manusia sejak lahir. Tanpa dengannya mustahil seseorang dapat hidup sebagai manusia secara utuh. Hak-hak ini berlaku pada setiap umat manusia tanpa memperhatikan faktor- faktor pemisah seperti ras, agama, warna kulit, kasta, kepercayaan, jenis kelamin, atau kebangsaan.

Sehubungan dengan hal tersebut, Eggi Sudjana mengemukakan bahwa pada hakekatnya hak-asasi manusia terdiri dari dua hak fundamental yang ada pada diri manusia yaitu hak persamaan dan hak kebebasan. Dari kedua hak ini, lahir hak-hak lain yang bersifat turunan. Adapun hak-hak turunan yang dimaksud meliputi segala hak- hak dasar seperti hak hidup, hak berpendapat, 
hak beragama, hak berpenghidupan yang layak, hak persamaan di muka hukum, hak milik, hak-hak memperoleh kecerdasan intelektual dan sebagainya. (Sudjana, 2001:4).

Meskipun demikian, dalam sejarahnya gagasan tentang hak asasi manusia tidak terpisahkan dengan aspek politik, Magna Charta tahun

1512 di Inggris misalnya, menggagas bahwa raja yang berkekuasaan absolut (menciptakan hukum) menjadi terbatas dapat dimintai pertanggungjawabannya di muka umum. Lahirnya Magna Charta kemudian diikuti peraturan sejenis yang lebih dikenal Bill of Right tahun 1689. Saat itu timbul adigium equality before the law (persamaan kedudukan dimuka hukum). Adigium inilah yang akhirnya mendorong timbulnya negara hukum dan demokrasi. (Sudjana, 2001:5).

Gagasan tentang hak-hak asasi manusia tersebut sebagai reaksi terhadap keabsolutan dan kaum feodal pada masa itu. Sebagai reaksi terhadap keadaan yang pincang (penguasa-rakyat, tuan-budak) maka timbullah gagasan agar lapisan bawah dapat dimerdekakan hak- haknya, sebab mereka adalah manusia perlu diangkat derajatnya dari kedudukan budak menjadi sama dengan lapisan atas. Dari keadaan yang demikian muncullah ide persamaan (egalite), persaudaraan (fraternite), dan kebebasan (liberte).

Dalam perkembangan berikutnya, HAM yang bentuknya sekarang ini, ditandai dengan lahirnya The American Declaration of Independence, (Deklarasi kemerdekaan) Amerika serikat 1776. Dalam deklarasi ini dipertegas, manusia adalah merdeka sejak ada di dalam perut ibunya, dan tidak lagi merdeka, setelah lahir mereka dibelenggu. Kemudian tahun 1789 lahir The French Declaration yaitu deklarasi HAM dan warga negara Perancis. Inti dari isi deklarasi tersebut adalah hak-hak asasi yang diperinci, sehingga melahirkan dasar The rule oflaw. Misalnya tidak boleh ditangkap dengan semena-mena, tidak diperkenankan menangkap orang tanpa alasan yang sah dan di tahan tanpa surat perintah. Asas praduga tak bersalah (presumption of innonce), kebebasan mengeluarkan pendapat, (freedom of expression), kebebasan beragama, (freedom of religion), dan pengaturan hak milik (the right of property). (Sudjana, 2001:5) 
Sejarah HAM memasuki babak baru setelah Perserikatan BangsaBangsa (PBB) mengeluarkan Universal Declaration of Human Right (UHDR) yang populer dikenal dengan deklarasi HAM Internasional tahun 1948. Sejak itu, konsep HAM berkembang tidak hanya berkaitan dengan hak politik dan sipil, tetapi juga pada hak-hak ekonomi dan sosial.

Mengapa hak-hak asasi manusia menjadi isu global yang saat ini diperbincangkan secara terus menerus, maka jawabannya adalah karena hak asasi manusia merupakan kebutuhan dasar yang diberikan oleh pencipta dan melekat pada diri manusia sejak lahir berupa hak hidup, hak beragama, hak berpendapat, hak berekspresi, hak berpenghidupan yang layak dan sebagainya. Oleh karenanya ia harus dilindungi dan diberikan kebebasan dan kemerdekaan sesuai dengan fitrahnya.

Gagasan tentang HAM tersebut diatas, bila dikaitkan dengan agama secara normatif tidak bertentangan, karena agama menjunjung tinggi nilai-nilai hak asasi manusia. Dalam agama terdapat sejumlah aturan normatif tekstual yang dapat dijadikan dasar bagi penegakkan HAM tanpa merasa perlu untuk melihat bagaimana landasan normatif itu dipratekkan oleh umatnya dalam realitas sejarah. Meskipun tidak ada pertentangan antara agama dan HAM dalam aspek normatifnya, namun ada perbedaan antara keduanya. Perbedaan itu terletak pada titik tolak pemikiran yang kemudian melahirkan yang berbeda pula. Kalangan agama meletakkan wahyu diatas nalar manusia dan berorientasi pada Tuhan (teosentris), sementara perumusan HAM internasional didasarkan atas nilai kemanusiaan atau yang berpusat pada manusia (antroposentris).

Untuk itu, penulis melakukan eksplorasi dengan menelusuri konsep HAM yang berkembang di dunia Barat yang menjadi isu global dewasa ini sehingga sangat perlu bagi umat Islam untuk merespon tentang hak-hak asasi manusia tersebut.

\section{Hegemoni Pemahaman HAM; Antara Teosentris dan}

\section{Antroposentris}

The Universal Declaration of Human Right (UDHR) sebagai 
deklarasi HAM internasional yang memproklamirkan deklarasi semesta hak-hak asasi manusia sebagai standar umum kemajuan bagi semua orang dan bangsa, dengan harapan bahwa setiap individu dan organ masyarakat yang menjunjung tinggi deklarasi ini secara terus menerus akan berjuang melalui pengajaran dan pendidikan untuk meningkatkan penghormatan terhadap hak-hak individu dan sosial melalui langkah-langkah progresif baik nasional maupun internasional.

Universal Declaration of Human right (UDHR) tersebut, dalam perjalanannya tidak mudah diterima dan dilaksanakan. Hal ini disebabkan di setiap wilayah, budaya dan keyakinan juga memiliki pemahaman tentang HAM yang boleh jadi secara prinsipil bertentangan dengan HAM universal tersebut. Negara-negara berkembang di Asia, Afrika ataupun negara yang berpenduduk mayoritas Islam, tidak hanya memiliki pemahaman yang berbeda, tetapi juga memiliki semangat yang berbeda dengan HAM universal, Islam misalnya beserta pemenuhannya terkait erat dengan masalah ketuhanan (teosentis), suatu pemaknaan yang berbeda sama sekali dengan yang ada di Barat maupun kelompok budaya lain.

Dalam sudut pandang ilmu alam, manusia adalah jagad kecil atau yang dikenal "mikrocosmos" yang merupakan cermin dari jagad besar, "makrokosmos", yang meliputi seluruh alam semesta. Manusia adalah ciptaan Tuhan yang menjadi khalifah (wakil Tuhan) di muka bumi. Setiap perbuatan yang membawa pada perubahan dan perbaikan pada sesama manusia memiliki nilai kebaikan dan keseluruhan seluruh kosmos, yang melintas batas jagad raya, menyimpan kebenaran dan kebaikan universal serta nilai yang berdimensi kemaslahatan.

Oleh karenanya, manusia memikul beban dan tanggung jawab yang cukup besar dihadapan Tuhan tanpa mungkin didelegasikan pada individu yang lain. Pertanggungjawaban yang diajukan pada seseorang harus dimulai dengan kebebasan memilih. Jika seseorang langsung dituntut suatu pertanggungjawabannya, maka tuntutan ini dianggap suatu kezaliman dan ketidakadilan. Untuk itu, kebebasan merupakan bagian yang tidak terpisahkan dari tanggung jawab. Selain itu, kebebasan juga diposisikan sebagai penghormatan JURNAL TRANSFORMATIF (Islamic Studies) 
atas harkat dan martabat manusia sebagai individu, hamba dan khalifah-Nya. Pelanggaran dan penindasan atas harkat dan martabat manusia dikategorikan sebagai kejahatan universal. (Sudjana, 2001:90)

Pemberian kebebasan terhadap individu-individu bukan berarti mereka dapat menggunakan kebebasan tersebut dengan mutlak, tetapi dengan kebebasan itu terkandung hak dan kepentingan orang lain yang harus dihormati. Dari sinilah muncul komitmen sosial antara individu dan kelompok dalam masyarakat.

Konsepsi tersebut dapat dipahami karena hak asasi manusia pada dasarnya adalah moral dan bukan politik. HAM menjadi hal yang penting sejak deklarasi hak asasi manusia oleh negara-negara anggota PBB. Konsep hak asasi manusia diperluas tidak hanya mengenai hak-hak sipil tradisional, tetapi juga hak-hak ekonomi dan sosial.

Hak-hak sipil dan politik meliputi misalnya hak untuk hidup (pasal 6), hak tentang kebebasan dan keamanan seseorang (pasal 9), hak persamaan di depan pengadilan dan diatas mimbar (pasal 14) hak kebebasan berpikir, kebebasan hati nurani dan kebebasan agama (pasal 18) hak untuk mempertahankan pendapat dan intervensi (pasal

19), hak melakukan pertemuan dengan tenang (pasal 21), hak kebebasan untuk berserikat (pasal 22), dan lain-lain. Hak-hak ekonomi, sosial dan budaya meliputi misalnya, hak untuk bekerja (pasal 6) hak untuk membentuk serikat pekerja (pasal 8), hak jaminan sosial (pasal 9), hak terhadap standar hidup bagi pribadi dan keluarganya (pasal 11), hak untuk memperoleh pendidikan (pasal 13), hak untuk berpartisipasi dalam kebudayaan (pasal 15) dan lain- lain.(Abdillah, 1999:95). Pada pasal 2 dalam deklarasi ini juga disebutkan bahwa setiap orang mempunyai hak-hak dan kebebasan- kebebasan serta tanpa adanya perbedaan apapun seperti perbedaan ras, warna kulit, jenis kelamin, bahasa, agama, tahanan politik, atau paham yang lain, nasional, atau asal-usul sosial, hak milik, kelahiran atau status yang lain. (Abdillah, 1999:19).

Dalam deklarasi tersebut HAM diartikulasikan secara universal, 
namun dalam interpretasi dan prakteknya mengalami perbedaan- perbedaan terutama pada negara-negara liberal, sosialis, bahkan negara-negara muslim pun berusaha memahami HAM dalam konteks ajaran Islam.

Negara Liberal memberikan prioritas terhadap hak-hak sipil dan politik, sedangkan negara-negara sosialis atau komunis memberikan hak-hak ekonomi dan sosial. Konsep hak asasi manusia yang universal kemudian diuraikan oleh beberapa negara dunia ketiga, terutama dengan maksud menerapkan konsep hak asasi manusia sesuai dengan kondisi dan budaya regional atau lokal. Dikalangan intelektual dan aktivis Muslim, mereka semua setuju tentang konsep hak asasi manusia, dan tentu saja konsep tentang hak asasi manusia sejalan dengan Islam. (Abdillah, 1999:97). Hal ini cukup masuk akal, karena istilah demokrasi tidak berasal dari bahasa Islam, tetapi berasal dari Barat, sedangkan esensi hak asasi manusia sejak awal telah diakui oleh Islam. Namun dalam kosa kata Arab ada kata haqq yang diterjemahkan secara tepat sebagai "hak" (right) dan hak asasi manusia yang disebut huquq al-Islam.

Namun demikian, istilah ini dan formulasinya baru populer di masyarakat Islam sejak awal abad ini. Hal ini karena ajaran-ajaran agama umumnya lebih menekankan kewajiban ketimbang hak. Hak- hak akan dicapai jika individu memenuhi kewajibannya. Ulama klasik telah menformulasikan istilah al-umur aldaruriyyah (kebutuhan manusia) dan al-umur al-Hajiyyah (kepentingan manusia) yang harus dipenuhi dan dipertahankan dalam kehidupan manusia. Istilah-istilah ini serupa dengan konsep tentang hak asasi manusia dewasa ini.

( Abdillah, 1999: 97)

Dalam pandangan Islam pada prinsipnya hak asasi manusia bukanlah berasal dari siapapun, melainkan berasal dari causa prima alam semesta ini yaitu Tuhan yang Maha Esa. Disinilah terdapat perbedaan yang mendasar antara konsep HAM dalam Islam dengan konsep HAM Barat seperti yang ada dalam masyarakat internasional. HAM dalam pandangan Islam, dikategorisasikan sebagai aktivitas yang didasarkan pada diri manusia sebagai khalifah Allah di muka bumi, sedangkan bagi pandangan Barat, HAM ditentukan oleh aturan- aturan publik demi tercapainya perdamaian dan keamanan semesta alam. 
Selain itu, perbedaan juga terdapat dalam cara memandang HAM itu sendiri. Islam, menurut pandangan yang sifatnya teosentris, mengandung aspek ketuhanan dan manusia hidup dimaksudkan untuk mengabdi kepada-Nya. Karenanya, nilai-nilai yang selama ini dikenal di dunia internasional, termasuk yang dianggap dari Barat sekalipun,

seperti demokrasi, kesejahteraan ekonomi, dan sebagainya diperuntukkan bagi tegaknya HAM yang berorientasi pada penghargaan manusia. Ukuran sesuatu mesti diselaraskan dengan keberadaan manusia, sehingga watak yang berkembang lebih dekat penghargaan individu-individu semata. Pemahaman inilah yang kemudian dikenal dengan antrophosentrisme.

Pemaknaan HAM yang berkembang di Barat telah menempatkan manusia dalam setting yang terpisah dengan Tuhan (devided God). Hak asasi manusia merupakan hak yang secara alamiah akan diperoleh seseorang sejak lahir. Perbedaan persepsi tentang manusia, hak-haknya, hingga nasibnya merupakan salah satu sebab yang memicu konflik antara dunia Barat dengan Timur, dalam hal ini adalah Islam. HAM adalah anugrah Tuhan, sehingga setiap individu harus bertanggung jawab pada Tuhan. (Sudjana, 2001:9-10)

Dari paparan tersebut, sangat jelas perbedaan antara pemahaman Barat yang dilatarbelakangi oleh sekularisme dengan pemahaman Islam yang menjunjung tinggi nilai-nilai ketuhanan. HAM di Barat hanya dipertanggungjawabkan pada sesama manusia, sedangkan dalam Islam pertanggungjawabannya kepada manusia dan kepada Tuhan. Dengan kata lain bahwa HAM bukan sekedar masalah kemanusiaan saja, tetapi juga masalah yang berhubungan dengan masalah ketuhanan (teosentris). Sebab, pada dasarnya, secara fitri manusia senantiasa menginginkan agar kebutuhan pokoknya terpelihara. Dalam hal ini sangat terkait dengan tujuan Tuhan menurunkan syari'at atau biasa disebut dengan istilah maqasid al-syari yang berintikan kemaslahatan manusia. Hal ini dapat dilihat pada Q.S. al-Maidah (5): 16; Q.S.al-An'am (6): 104; Q.S. Yunus (10): 57, 58 dan 108. 
Dengan demikian ajaran agama (Islam) memandang bahwa manusia itu adalah satu umat yang disatukan oleh arti dan nilai kemanusiaan yang secara asasi memiliki kedudukan yang sama.

Demikian luhurnya ajaran Islam tentang HAM seperti yang tersebut diatas. Namun dalam tataran praksisnya, pelaksanan HAM terjadi hegemoni Barat terhadap dunia Timur dalam hal ini Islam. Proses hegemoni ini melalui kekuasaan ekonomi, politik, budaya hingga media komunikasi internasional. Hegemoni dunia Barat tersebut sangat mempengaruhi pola pikir masyarakat dalam memahami tentang hak-hak asasi manusia.

\section{Respon Islam terhadap Hak-hak Asasi Manusia}

Wacana yang berkembang tentang hak asasi manusia dewasa ini bersumber dari kehidupan Barat. Diskursus tentang hal tersebut belum selesai d1perdebatkan. Di satu pihak mengklaim bahwa HAM hendaknya dilaksanakan secara seragam dan menyeluruh di seluruh penjuru dunia. Di lain pihak menghendaki penegakkan HAM dan konsepsinya dari sudut pandang yang lebih spesifik dan sesuai dengan kondisi budaya dan keyakinan masyarakat setempat.

Dalam hubungan ini, Islam membicarakan tentang HAM merupakan pemberian dari pencipta karena manusai diberikan keistimewaan atau kemuliaan (Q.S al-Isra': 70). Allah juga mengangkat harkat dan martabat manusia dengan menjadikannya sebagai khalifah di muka bumi (QS. alBaqarah,:30). Nabi di utus sebagai pembawa rahmat bagi semesta alam (Q.S. alAnbiya'107).

Untuk mewujudkan risalah tersebut, Islam menanamkan teologi monoteisme. Teologi ini mampu memberikan inspirasi dan inovasi jauh kedepan bagi terwujudnya rahmat li al-'alamin, sebab pengakuan atas teologi monoteisme berarti juga mengekohkan sikap indepedensi dengan menegaskan bahwa segala bentuk kekuasaan adalah milik Allah. Dari sinilah sestem perbudakan dihancurkan, otoritarianisme penguasa dibasmi serta absolutisme raja dipangkas.

Untuk mengelaborasikan teori pembebasan tersebut, Rasulullah 
membangun suatu komunitas masyarakat baru yang di bawah payung "piagam madinah". Masyarakat tersebut bersifat pluralisme yang mewadahi seluruh komponen termasuk kaum Yahudi, Nasrani, Muslim, Majusi, dan sebagainya.(Muhammad, 2003:36).

Demikian pula dakwak Nabi Muhammad ditutup dengan pesan yang disampaikan pada khutbah haji Wada' dengan menegaskan bahwa "belum sempurna keislaman seseorang jika dalam kehidupannya tidak menghormati dan menjujung harkat dan martabat manusia, baik laki-laki maupun wanita. Dalam sabda Nabi " Tidaklah beriman seseorang kamu sehingga kamu mencintai saudaramu sebagaimana kamu mencintai dirimu sendiri”

Sehubungan dengan hal tersebut, ada beberapa hal yang perlu disikapi tentang hak asasi manusia adalah sebagai berikut:

1. Hifzh al-Din, yaitu memberikan jaminan hak kepada umat Islam untuk memelihara agama dan keyakinannya. Islam juga menjamin sepenuhnya atas identitas agama yang bersifat lintas etnis. Oleh karena itu, Islam menjamin kebebasan beragama dan melarang adanya pemaksaan agama yang satu dengan yang lain

2. Hifzh al-Nafs wa al-'irdh, yaitu memberikan jaminan hak atas setiap jiwa (nyawa) manusia, untuk tumbuh dan berkembang secara layak. Dalam hal ini Islam menuntut adanya keadilan, pemenuhan kebutuhan dasar (hak atas penghidupan) pekerjaan, hak kemerdekaan dan keselamatan, bebas dari penganiyaan dan kesewenag-wenangan.

3. Hifzh al- Aql, adalah adanya suatu jaminan atas kebebasan berekspresi, kebebasan mimbar, kebebasan mengeluarkan opini, melakukan penelitian, dan berbagai aktivitas ilmiah. Dalam hal ini melarang terjadinya perusakan akal dalam bentuk penyiksaan, penggunaan ekstasi, minuman keras dan lain-lain.

4. Hifzh al Nasl, yaitu jaminan atas kehidupan privasi setiap individu, perlindungan atas profesi (pekerjaan), jaminan masa depan keturunan dan generasi penerus yang lebih baik dan berkualitas. Karena 
itu, Free sex, zina, homoseksual, menurut syara' adalah perbuatan yang dilarang karena bertentangan dengan hifzh al-nasl.

5. Hifzh al-Mal, ialah sebagai jaminan atas kepemilikan harta benda, properti dan lain-lain. Larangan adanya tindakan mengambil harta orang lain, mencuri, korupsi, monopoli, dan lain-lain.

(Muhammad, 2003:36-37)

Mencermati hal tersebut diatas, dapat dipahami bahwa Islam sebagai agama sangat menghormati hak-hak yang ada pada diri manusia termasuk dalam hal penegakkan hukum. Antara hak-asasi manusia dengan hukum adalah bagian integral yang tak dapat dipisahkan. Berpikir tentang hukum otomatis akan berkaitan dengan ide bagaimana keadilan dan ketertiban dapat terwujud. Pengakuan dan pengukuhan hukum pada hakikatnya ditujukan untuk menjamin terjaganya hak asasi manusia. (Sudjana, 2001:47). Persamaan yang dimiliki oleh manusia di muka hukum, tanpa ada perbedaan etnis, agama bangsa, keturunan, kelas, dan kekayan. Juga tanpa dibedakan antara muslim, nasrani, atau lainnya, antara cendekiawan dengan yang bukan, antara yang kuat dengan yang lemah.

Hal ini disampaikan pula dalam Declaration Cairo on Human right in Islam dinyatakan bahwa manusia mempunyai hak yang sama dalam hukum dan bebas dari praduga tak bersalah sebelum diputuskan oleh hakim di pengadilan, seperti dalam pasal 19 yang berbunyi:

Semua individu adalah sederajat dimuka hukum tanpa ada perbedaan antara yang memerintah dengan yang diperintah.

Hak untuk mendapatkan keadilan dijamin bagi setiap orang. Tanggung jawab adalah dipikul oleh setiap orang yang melakukan.

Tidak boleh ada kejahatan atau penghukuman kecuali yang ditetapkan oleh syari' at.

Terdakwa dinyatakan tidak bersalah sampai ia terbukti bersalah di pengadilan dimana ia diberi jaminan untuk membela diri.(Abdillah, 1999:98). 
Makna yang terkandung dalam pasal tersebut khususnya pada ayat b dan $\mathrm{c}$ sesuai dengan firman Allah (Q.S. an-Nisaa'(4):58. Ini membuktikan betapa pentingnya penegakkan hukum secara adil sebagai realisasi terhadap hak asasi manusia, karena penegakan hukum sebagai kebutuhan asasi, agar apa yang dimiliki oleh manusia dapat terlindungi.

Dengan demikian hak asasi dalam Islam bukanlah sesuatu yang berhubungan secara langsung dengan aspek politik melainkan berkaitan dengan aspek moral yaitu bentuk perlindungan pada diri manusia. Perlindungan ini dapat dibagi menjadi beberapa aspek yaitu:

1. Perlindungan terhadap keturunan manusia.

2. Perlindungan terhadap akal.

3. Perlindungan terhadap kehormatan

4. Perlindungan terhadap jiwa.

5. Perlindungan terhadap harta

6. Perlindungan terhadap agama.

7. Perlindungan terhadap rasa aman.

8. Perlindungan terhadap batas negara.(Abdillah, 1999:136)

Hal yang sama juga disebutkan oleh Abul A'la Al-Maududi tentang hak-hak asasi manusia sebagai berikut:

1. Perlindungan nyawa, kehormatan dan harta benda.

2. Kebebasan mengeluarkan pokok pikiran, pendapat, keyakinan dan peribadatan.

3. Kebebasan bergerak di seluruh wilayah negara.

4. Kebebasan berserikat dan berkumpul.

5. Kebebasan menganut suatu propesi atau pekerjaan dan hak untuk memiliki, memperoleh atau memindah tangankan harta kekayaan.

6. Kesamaan kesempatan di semua lapangan kehidupan dan hak yang sama untuk menikmati manfaat dari semua fasilitas umum. (Hikmat, 1994:340).

Demikian pula Abu Zahra dalam bukunya Ushul al-Figh menyatakan bahwa syari'at diturunkan sebagai rahmat bagi manusia. Dalam arti bahwa agama datang JURNAL TRANSFORMATIF (Islamic Studies) 
untuk memberikan pertolongan serta melindungi nilai- nilai kemanusiaan terutama menyangkut kebutuhan al-daruryiyah. Lebih jauh Abu Zahra menjelaskan kebutuhan al-daruriyyah yang dilindungi adalah Agama, jiwa, harta, akal, dan keturunan.(Abu Zahra, t.th.:367).

Sehubungan dengan hal ini Al-syatibiy mengemukakan bahwa Aldaruriyyah adalah segala sesuatu yang mesti ada untuk mewujudkan kemaslahatan hidup manusia baik di dunia maupun di akhirat. Bilamana kebutuhan daruriyat ini tidak terpenuhi, maka kemaslahatan dunia akan rusak dan kebahagiaan ukhrawi akan hilang. (Al-Syatibiy, t.th.:7-8)

Dengan demikian, ajaran Islam sebagaimana yang telah dikemukakan oleh tokoh intelektual muslim tersebut memposisikan manusia dalam posisi yang terhormat dan mulia. sehingga konsep hak- hak asasi manusia merupakan salah satu aspek yang penting untuk dikaji, dipahami dan lebih penting dari itu adalah dilaksanakan dalam kehidupan individu dan sosial agar keselamatan dan kemaslahatan dapat terwujud.

Dalam konteks kehidupan di Indonesia, para pakar inteleketual muslim mendukung pelaksanaan hak asasi manusia. Abdurrahman Wahid misalnya berpendapat,“ Manusia mempunyai posisi tinggi dalam kosmologi, sehingga ia harus diperlakukan secara proporsional pada posisi yang "mulia". Sebelum seorang individu dilahirkan dan setelah meninggalnya, dia mempunyai atau tetap mempunyai hak-hak yang diformulasikan dan dilindungi secara jelas oleh hukum. Karena individu mempunyai hak dan kemampuan untuk menggunakannya, Allah menjadikannya sebagai khalifah-Nya di muka bumi, sebagaimana dinyatakan secara eksplisit dalam al-Qur'an. Kecendrungan manusia untuk menyalahgunakan haknya tidak menurunkan posisinya yang tinggi, sehingga dapat dipahami bahwa teologi Islam tidak mengakui dosa warisan. Memang ada

keseimbangan tertentu antara hak-hak yang dipunyai seorang muslim dan kewajibannya kepada Allah, tetapi hak-hak ini tidak dapat disangkal menunjukkan kebebasan berkehendak dan kebebasan untuk memilih. Kebebasan ini kemudian JURNAL TRANSFORMATIF (Islamic Studies) 
menunjukkan dasar yang kuat bagi pemeliharaan dan perkembangan hak-hak asasi manusia dalam Islam".(Wahid, 1983: 94-95)

Intelektual muslim lainya sebagaimana yang disebutkan oleh Masykuri Abdillah memandang istilah hak-asasi manusia sebagai respon terhadap Deklarasi Universal Hak Asasi Manusia. Ali Yafie misalnya mendukung hak asasi manusia dengan argumen tentang konsep Maslahah (kepentingan umum), yang diperkenalkan oleh fukaha klasik. Al Yafie berpendapat bahwa kebutuhan dasar manusia (al-daruriyyah) meliputi jiwa (al-nafs), akal (al-aql), keturunan (alnasab) harta benda (al-mal) dan agama (al-din). Islam melindungi kebutuhan dasar manusia dan melarang pelanggaran apapun terhadap kebutuhan dasar manusia tersebut.(Abdillah, 1999:101)

Dalam teori hukum (ushul al-figh) ada kaidah yang menyatakan bahwa “tujuan umum syari'ah Islam adalah mewujudkan kepentingan umum melalui perlindungan dan jaminan kebutuhan-kebutuhan dasar (al-daruriyyah) serta pemenuhan kepentingan (al-hajiyyat) dan penghiasan (tahsiniyyah) mereka. (Khallaf, 1978:199)

Dengan demikian, konsepsi Islam tentang HAM yang di temukan dalam al-Qur'an dan hadis Nabi maupun penafsiran terhadapnya yang dikemukakan oleh pakar (intelektual) muslim mengakui HAM sebagai aspek yang berkaitan dengan kemuliaan manusia yang mengatur kehidupan individual dan sosial. Bahkan dalam kehidupan modern dewasa ini tidak dapat dipungkiri persentuhan antara agama, budaya, suku, politik, ekonomi, dan keamanan yang membentuk pola-pola interaksi antara Islam dan budaya-budaya lainnya dan berusaha meningkatkan keadaan mereka.

Mencermati pemahaman HAM dalam Islam maupun interpretasi intelektual muslim terhadap HAM tersebut, maka dapat dipahami bahwa konsep Hak Asasi Manusia merupakan anugrah dari pencipta yang harus dilindungi karena berkaitan dengan kemuliaan manusia sebagai makhluk ciptaan Allah, sebagai hamba yang mengabdi kepada-Nya dan sebagai khalifah untuk membangun kemaslahatan di dunia. Oleh karenanya semua bentuk yang bertentangan dengan nilai- nilai kemanusiaan dan konsep teologis dalam Islam tidak dapat JURNAL TRANSFORMATIF (Islamic Studies) 
dilakukan meskipun dalam melakukannya atas nama hak asasi manusia.

\section{Penutup}

Sebagai akhir dari tulisan ini, dapat disimpulkan sebagai berikut:

1. HAM merupakan fitrah manusia yang diberikan oleh pencipta. Oleh karenanya, harkat dan martabat manusia harus dilindungi baik sebagai individu, makhluk sosial, maupun sebagai hamba dan khalifah-Nya. Pelanggaran dan penindasan terhadap manusia merupakan kejahatan universal terhadap nilai-nilai kemanusiaan.

2. Hak asasi manusia dalam pemahaman HAM hasil deklarasi internasional (pernyataan semesta hak asasi manusia 1948) hanya didasarkan pada nilainilai kemanusiaan yang berpusat pada manusia (antroposentris), sehingga pertanggungjawabannya hanya kepada manusia karena HAM ditempatkan pada setting yang terpisah dengan Tuhan. Sedangkan HAM dalam perspektif Islam didasarkan pada nilai-nilai ketuhanan (teosentris) dan antroposentris sekaligus, sehingga pertanggungjawabannyapun kepada Tuhan dan kepada manusia.

3. Dalam tataran praktek pelaksanaan HAM terjadi hegemoni Barat. Proses hegemoni ini melalui kekuasaan ekonomi, politik, budaya hingga media komunikasi internasional. Hegemoni tersebut sangat mempengaruhi pola pikir masyarakat dalam memahami hak asasi manusia.

4. Dikalangan intelektual muslim dalam meresponi tentang hak asasi manusia sependapat bahwa penegakan hak asasi manusia tidak bertentangan dengan ajaran Islam. Sebab dalam Islam manusia ditempatkan dalam posisi yang terhormat dan mulia baik secara individual, kolektif dan politis. Disamping itu, manusia memiliki kebutuhan dan kepentingan yang harus dipenuhi dan dipertahankan dalam kehidupannya. Oleh karenanya, Islam memberikan perlindungan dan mendukung terhadap tujuan pembangunan dan pembentukan moralitas manusia khususnya yang berkenaan dengan penegakan hak-hak asasi manusia. 
E-ISSN : 2580-7056, ISSN : 2580-7064

Pascasarjana IAIN Palangka Raya

\section{Daftar Pustaka}

Abdillah, Masykuri. 1999. Demokrasi di Persimpangan Jalan, Respon Intelektual Muslim Indonesia Terhadap Konsep Demokrasi (1966-1993). Cet.I Yogyakarta: Tiara Wacana Yogya.

Ali Muhammad, Rusjdi. 2003. Revitalisasi Syari'at Islam di Aceh, Problem, solusi dan Implementasi. Cet. I.. Jakarta: Logos Wacana Ilmu.

Al-Amidiy, Saif al-Din abi Hasan ibn Ali Muhammad .1981. Al-Ihkam fi Usul al-Ahkam. Jilid III. Dar al-Fikr.

Khallaf, Abd. Al-Wahhab 1978. Ilm Ushul al-Fiqh. edisi 12. Kuwait: Dar alQalamq

Al-Maududi, Abul A'la. 1994. The Islamic Law and Constitution, Diterjemahkan Oleh Asep Hikmat dengan judul Hukum dan Konstitusi Sistem Politik Islam. Cet. III. Bandung: Mizan.

Sudjana, Eggi. 2002. Hak dalam Perspektif Islam, Mencari Universalitas HAM bagi Tatanan Modernitas yang Hakiki. Cet. I.. Jakarta: Nuansa Madani.

Al-Syatibiy, Abu Ishak, t.th. Al-Muwafaqat fi ushul al-Syari'at, Jilid II. Bairut: Dar al-Kutub al-Ilmyyah.

Wahid, Abdurrahman. 1983. Muslim di Tengah Pergumulan. Jakarta: Leppenas.

Al-Zahra, Abu. t.th. Ushul al-Fiqh. Dar al-Fikr al-Arabiy. 